\title{
RANCANG BANGUN FREKUENSI METER LISTRIK BERBASIS ATMEGA328
}

\author{
Bima Adhi Nugroho*), Sudjadi, Yuli Christyono \\ Departemen Teknik Elektro, Universitas Diponegoro, Semarang \\ Jl. Prof. Sudharto, SH, Kampus UNDIP Tembalang, Semarang 50275, Indonesia \\ ${ }^{*}$ E-mail: bimadhi93@gmail.com
}

\begin{abstract}
Abstrak
Frekuensi merupakan jumlah gelombang dalam satu detik. Frekuensi listrik adalah banyaknya gelombang listrik yang terdapat dalam satu detik. Frekuensi listrik merupakan salah satu parameter gelombang listrik yang dapat mempengaruhi kinerja dari sistem tenaga listrik. Perubahan nilai frekuensi listrik bagi sebagian perangkat dapat berpengaruh besar. Salah satu akibat dari frekuensi listrik yang tidak stabil adalah mengakibatkan perputaran motor listrik sebagai penggerak mesin-mesin produksi pada industri manufaktur menjadi tidak stabil, dimana hal ini akan mengganggu proses produksi. Frekuensi listrik di Indonesia berada pada kisaran $50 \mathrm{~Hz}$, perubahan pada besar nilai frekuensi masih dapat ditolerir apabila masih berada dalam batas. Karena itu penting untuk mengembangkan suatu alat untuk memantau besar nilai frekuensi listrik secara real-time. Frekuensi meter listrik yang dibuat untuk mengukur dan memantau besar frekuensi listrik. Alat yang dibuat untuk penelitian kali ini merupakan suatu sistem yang didesain untuk mengukur dan mengamati besar frekuensi listrik, mengumpulkan data perubahan frekuensi secara berkala, serta menjadi sistem peringatan dini apabila nilai frekuensi listrik melewati ambang batas yang ditentukan. Maka dibuatlah frekuensi meter listrik dengan menggunakan sistem data log yang terhubung ke komputer yang diharapkan memudahkan pengguna untuk mengecek terjadinya perubahan naik turunnya frekuensi listrik. Sehingga pengguna dapat mengetahui besar perubahan frekuensi listrik yang terjadi setiap saat.
\end{abstract}

Kata Kunci: Frekuensi, Frekuensi Listrik, Frekuensi Meter.

\begin{abstract}
Electricity frequency is the number of electrical waves contained in one second. Electricity frequency is one of the electrical wave parameters that can affect the performance of the electric power system. Changes in the electric frequency value for some devices can have a major effect. One of the consequences are the rotation of the electric motor as a driver of production machinery in the manufacturing industry becomes unstable, which will disrupt the production process. Therefore it is important to develop a tool to monitor the magnitude of the frequency in real-time. The frequency meter is made to measure and monitor the frequency of electricity. The tool made for this study is a system designed to measure and observe the frequency of electricity, collect data on frequency changes periodically, and become an early warning system if the value of electric frequency passes the specified threshold. Then the frequency meter is made using a log data system that is connected to a computer that is expected to make it easier for users to check for changes of electrical frequencies. So that users can find out the amount of changes in electrical frequency that occur at any time.
\end{abstract}

Keywords: Frequency, Electrical Frequency, Frequency Meter

\section{Pendahuluan}

Frekuensi merupakan jumlah gelombang dalam satu detik. Frekuensi listrik adalah banyaknya gelombang listrik yang terdapat dalam satu detik.[1] Frekuensi listrik merupakan salah satu parameter gelombang listrik yang dapat mempengaruhi kinerja dari sistem tenaga listrik.[2]

Perubahan nilai frekuensi listrik bagi sebagian perangkat dapat berpengaruh besar. Salah satu akibat dari frekuensi listrik yang tidak stabil adalah mengakibatkan perputaran motor listrik sebagai penggerak mesin-mesin produksi pada industri manufaktur menjadi tidak stabil, dimana hal ini akan mengganggu proses produksi.[3]

Alat yang dibuat untuk tugas akhir kali ini merupakan suatu sistem yang didesain untuk mengukur dan mengamati besar frekuensi listrik, mengumpulkan data perubahan frekuensi secara berkala, serta menjadi sistem peringatan dini apabila nilai frekuensi listrik melewati ambang batas yang ditentukan. Maka dibuatlah frekuensi 
meter listrik dengan menggunakan sistem data log yang terhubung ke komputer yang mana diharapkan memudahkan pengguna untuk mengecek terjadinya perubahan naik turunnya frekuensi listrik. Sehingga pengguna dapat mengetahui besar perubahan frekuensi listrik yang terjadi setiap saat.

\section{Metode}

\subsection{Perancangan Frekuensi Meter}

Berdasarkan dari kebutuhan spesifikasi, maka komponen perangkat digunakan pada tugas akhir ini antara lain : Transformator untuk menurunkan tegangan, rangkaian zero-cross detector utuk pengkondisi sinyal, rangkian sistem minimum mikrokontroller Atmega328 sebagai penghitung sinyal, dan LCD display sebagai penampil utama.

Mikrokontroller yang digunakan diprogram dengan menggunakan bahasa pemrograman $\mathrm{C}$ dengan compiler CodeVisionAVR. Mikrokontroller Atmega328 bertindak sebagai pemroses utama ketika mikrokontroller dinyalakan, mikrokontroller melakukan pemanggilan fungsi inisialisasi awal seperti pengaturan awal interupsi eksternal, mengaktifkan komunikasi UART, mengaktifkan fungsi $\mathrm{I}^{2} \mathrm{C}$ dan pengaturan awal RTC. Selanjutnya mikrokontroller akan menunggu adanya sinyal masukan dari blok pengkondisi sinyal. Setelah mendapat sinyal masukkan maka mikrokontroller akan segera menghitung jumlah frekuensi dan menampilkan berapa jumlah sinyal yang masuk.

Pada Rancangan sistem Frekuensi Listrik dapat dilihat bahwa input sistem berupa tegangan AC 220v yang selanjutnya tegangan diturunkan dengan menggunakan transformator. Kemudian sinyal listrik hasil keluaran transformator diproses oleh zero-crossing detector. Sinyal yang akan masuk kedalam rangkaian mikrokontroller harus memenuhi syarat tertentu seperti bentuk sinyal kotak dan tegangan harus bernilai 3,3-5,5V.

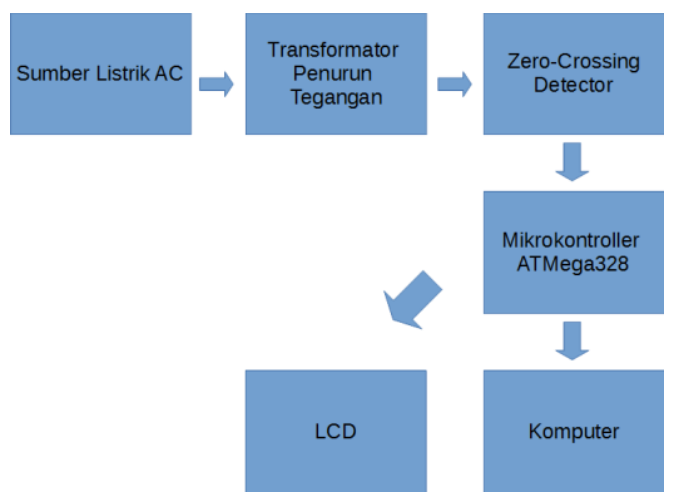

Gambar 1. Rancangan sistem Frekuensi Listrik

Sinyal yang didapatkan dari transformator belum memenuhi syarat tersebut, sehingga dibutuhkanlah blok pengkondisi sinyal untuk emndapatkan sinyal seperti yang diinginkan. Blok pengkondisi sinyal terdiri dari rangkaian zero-cross detector dan sebuah optocoupler. Dimana sinyal keluaran transformator yang berbentuk sinusoidal dan memiliki tegangan sebesar $17 \mathrm{~V}$, akan diubah menjadi sinyal kotak dengan tegangan sebesar $5 \mathrm{~V}$ yang dibutuhkan oleh mikrokontroller untuk kemudian dihitung frekuensi sinyal tersebut.

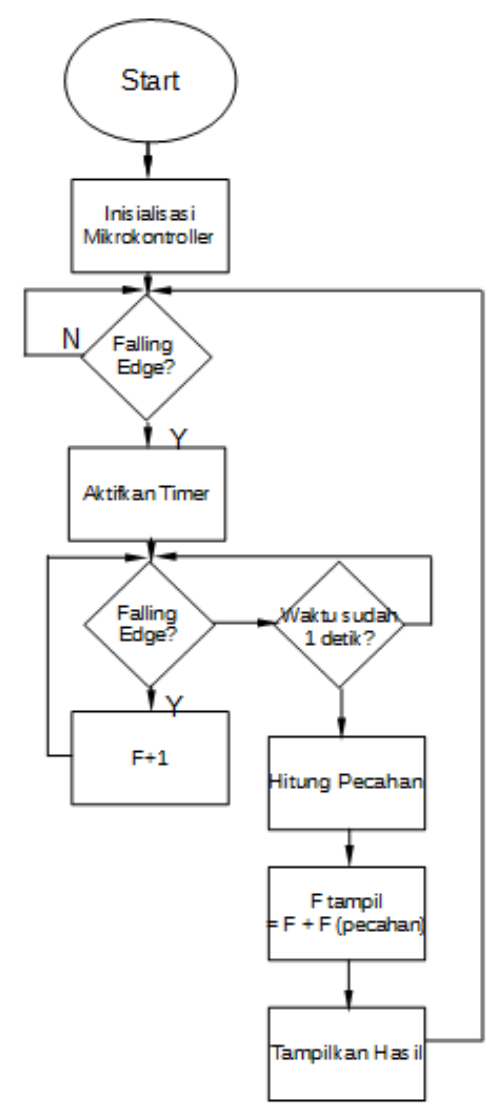

\section{Gambar 2 Diagram Alir Frekuensi Meter}

Diagram alir kerja frekuensi meter dapat dilihat pada gambar 2. Terdapat beberapa proses pada diagram alir kerja, berikut adalah penjelasan dari proses tersebut:

1. Inisialisasi Counter

Pada proses ini register counter pada mikrokontroller dikembalikan nilainya ke keadaan 0 sebagai awal memulai perhitungan.

2. Hitung Jumlah Falling Edge

Pada tahap ini mikrokontroller menghitung gelombang yang lewat berdasarkan jumlah falling edge dari gelombang kotak. Setiap falling edge yang terhitung akan menambah nilai counter sebesar 1.[3]

3. Mikrokontroller mengkonfirmasi waktu 1 detik Setiap penambahan nilai pada counter, mikrokontroller akan mengecek dan 
mengkonfirmasi apakah waktu perhitungan sudah mencapai 1 detik. Apabila waktu belum mencapai 1 detik, maka mikrokontroller akan melanjutkan perhitungan jumlah gelombang. Apabila sudah mencapai 1 detik, maka perhitungan dilanjutkan dengan perhitungan fraction.

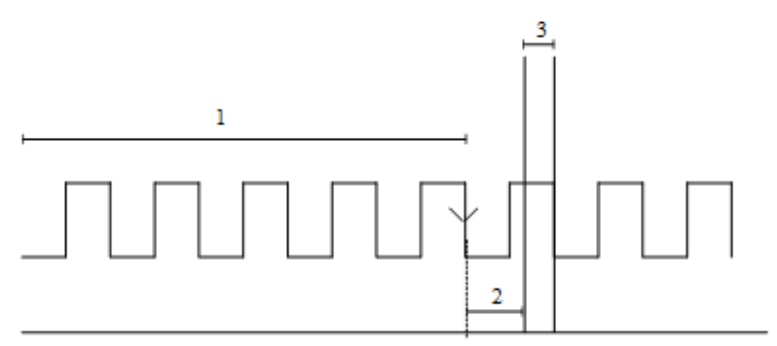

$1 \mathrm{~s}$

Gambar 3. Diagram Perhitungan Fraction

Dapat dilihat pada diagram perhitungan jumlah dari angka 1 dan 2 menunjukkan jumlah frekuensi yang terhitung pada waktu 1 detik, dimana untuk angka 1 menunjukkan jumlah frekuensi (f) dalam angka bilangan bulat dan angka 2 menunjukkan angka pecahan desimal. Sementara untuk angka 3 menunjukkan jeda antara satu detik hingga falling edge setelahnya atau awal siklus perhitungan frekuensi yang berikutnya.

Untuk mendapatkan hasil perhitungan jumlah frekuensi kita dapat menggunakan rumus 1 dan 2 .

$$
\begin{aligned}
& f(\text { fraction }) \\
& =\frac{\text { Selisih Timestamp }}{\text { Selisih Timestamp }+ \text { Timestamp } 2} \\
& F(\text { total })=f+f(\text { fraction })-1
\end{aligned}
$$

Dimana :

$\begin{array}{ll}f(\text { fraction }) & =\text { nilai pecahan dari frekuensi } \\ \text { Selisih Timestamp } & =\text { jeda antara falling edge terakhir } \\ & \text { dengan batas 1 detik } \\ \text { Timestamp2 } & \text { = jeda antara waktu satu detik } \\ & \text { dengan falling edge setelahnya }\end{array}$

\subsection{Perancangan Perangkat Lunak}

Pada perancangan perangkat penghitung frekuensi meter terdapat modul USB-to-serial yang berfungsi mengubah data serial UART menjadi bentuk yang bisa dibaca oleh komputer.

Perancangan perangkat lunak ini ditujukan pada blok komputer. Pada perancangan ini secara garis besar mengatur kerja sistem seperti pemilihan port serial untuk komunikasi serial, penampilan data dan penyimpanan data.

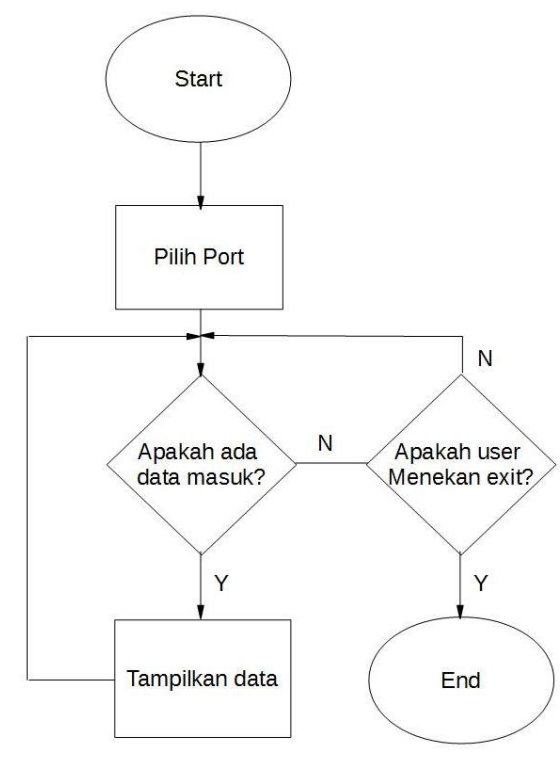

Gambar 4. Diagram alir perangkat lunak frekuensi meter.

Diagram alir kerja sistem dapat dilihat pada gambar 4 . Terdapat beberapa proses pada diagram alir kerja sistem, berikut adalah penjelasan dari proses tersebut:

1. Proses pemilihan port serial

Pada proses ini Server memindai port serial yang tersambung dan menampilkannya pada droplist pada GUI. Sehingga pengguna dapat memilih port serial yang tepat untuk berkomunikasi. Setelah port serial dibuka, maka menu lainnya pada GUI dapat digunakan.

2. Program menunggu data masuk

Pada tahap ini program menunggu apakah ada data yang masuk melalui port serial. Apabila ada data masuk maka data akan ditampilkan, namun apabila tidak ada data yang masuk maka program akan terus berjalan tanpa menampilkan apapun.

3. Menekan tombol exit

Apabila user menekan tombol exit maka program secara otomatis memunculkan jendela pop up yang akan menanyakan apakah pengguna akan menyimpan data atau tidak. Apabila pengguna ingin menyimpan data maka data akan disimpan sebelum program ditutup, apabila tidak maka program akan langsung tertutup.

\section{Hasil dan Analisis}

Pada pengujian ini akan dilakukan pada semua komponen pada frekuensi meter listrik. Data diambil menggunakan osiloskop pada 3 titik seperti pada gambar 5 . 


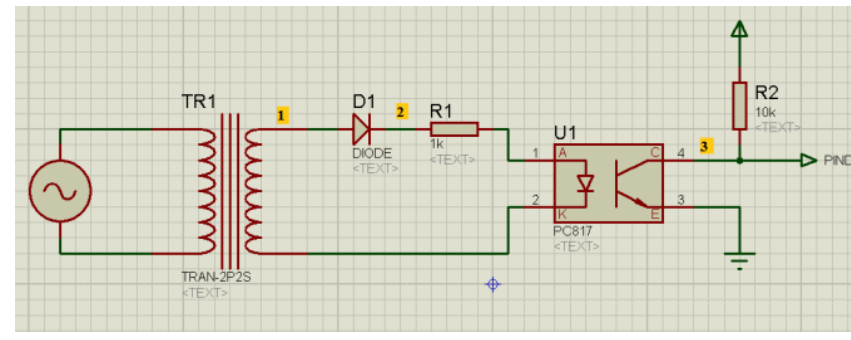

Gambar 5. Rangkaian Pengambilan Data

\subsection{Pengujian Komponen Frekuensi Meter}

Pengujian pada rangkaian ini adalah untuk mengetahui apakah bentuk sinyal keluaran dari rangkaian sudah sesuai. Pengujian dilakukan pada titik 1, dimana titik tersebut merupakan sinyal keluaran dari transformator. Bentuk keluaran sinyal dari transformator dapat dilihat pada gambar

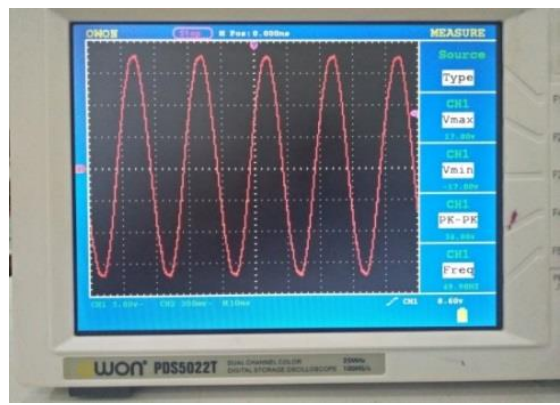

Gambar 6. Sinyal keluaran transformator

Dari gambar 6 dapat dilihat sinyal keluaran transformator berbentuk sinusoidal dengan amplitudo 17V. Ini menunjukkan bahwa sumber listrik AC berhasil diturunkan dari tegangan $220 \mathrm{~V}$ menjadi $17 \mathrm{~V}$ dengan bentuk gelombang yang sama. Hal tersebut menunjukkan bahwa komponen transformator telah bekerja dengan baik.

\subsection{Pengujian Dioda}

Pengujian pada rangkaian ini adalah untuk mengetahui apakah bentuk sinyal keluaran dari rangkaian sudah sesuai. Pengujian dilakukan pada titik 2, dimana titik tersebut merupakan tahapan dari proses perubahan dari sinyal sinusoidal sebelum menjadi sinyal kotak.

Pengujan dilakukan dengan melihat bentuk sinyal setelah sinyal tersebut melewati dioda yang terdapat pada rangkaian zero-crossing detector. Pengujian pada titik ini dilakukan untuk mengetahui apakah dioda sudah berfungsi dengan baik. Bentuk sinyal hasil pengukuran dapat dilihat pada gambar

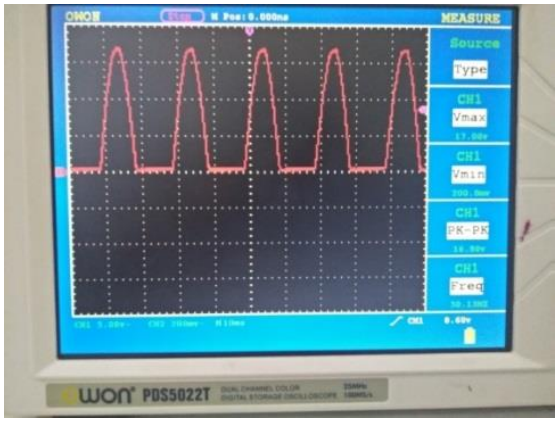

Gambar 7. Sinyal keluaran dioda

Dari gambar 7 telihat bahwa bentuk sinyal setelah melewati dioda berbentuk sinusoidal dan hanya mempunyai tegangan yang bernilai positif, dimana dioda hanya melewatkan tegangan positif. Hal tersebut menunjukkan bahwa dioda sudah berfungsi dengan baik.

\subsection{Pengujian Optocoupler}

Pengujian pada rangkaian ini adalah untuk mengetahui apakah bentuk sinyal keluaran dari rangkaian sudah sesuai. Pengujian dilakukan pada titik 3, dimana titik tersebut merupakan tahapan akhir dari proses perubahan dari sinyal sinusoidal menjadi sinyal kotak.

Pengujan dilakukan dengan melihat bentuk sinyal setelah sinyal tersebut melewati optocoupler. Pengujian pada titik ini dilakukan untuk mengetahui apakah komponen sudah berfungsi dengan baik. Bentuk sinyal hasil pengukuran dapat dilihat pada gambar.

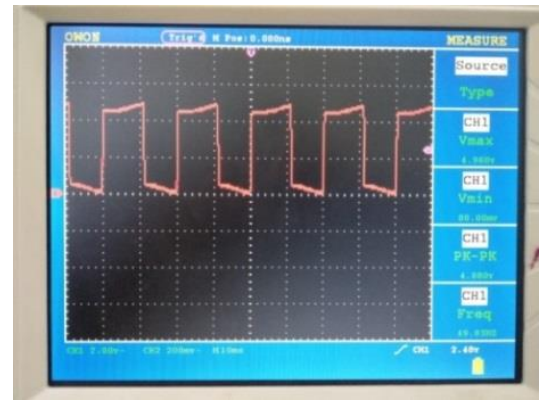

Gambar 8. Sinyal keluaran blok pengkondisi sinyal

Dari gambar 8 terlihat bahwa sinyal keluaran optocoupler sudah berbentuk kotak dengan amplitudo 4,9V. Hal tersebut menujukkan bahwa komponen optocoupler dan rangkaian pengkondisi sinyal sudah berfungsi dengan baik. Sinyal keluaran dari blok pengkondisi sinyal ini nanti akan masuk ke mikrokontroller

\subsection{Pengujian Pengambilan Data}

Pengujian dilakukan dengan membandingkan besar nilai frekuensi yang terhitung oleh mikrokontroller ATmega328. Pengujian ini dilakukan untuk mengetahui 
apakah hasil perhitungan frekuensi yang dilakukan sistem frekuensi meter mampu mendapatkan hasil yang akurat. Pengujian dilakukan dengan membandingkan nilai frekuensi listrik yang dihitung melalui mikrokontroller Atmega328 dengan nilai yang tertera pada multimeter.

Untuk pengujian akan dihitung galat relatif untuk mengetahui kemampuan dari alat tersebut dengan persamaan 3 dan galat relatif rata-rata dengan persamaan 4.

$$
\begin{aligned}
& \text { Galat relatif } \\
& =\frac{\text { Hasil alat pembanding }- \text { Hasil alat Ukur }}{\text { Hasil alat pembanding }} \times 100 \%
\end{aligned}
$$$$
\text { Galat relatif rata }- \text { rata }=\frac{\sum \text { Galat Relatif }}{n}
$$

Tabel 1. Hasil pengujian data frekuensi meter dan Sanwa CD800a Digital Multimeter terhadap besar nilai frekuensi.

\begin{tabular}{cccccc}
\hline No. & $\begin{array}{c}\text { Waktu } \\
\text { (detik) }\end{array}$ & Multimeter(Hz) & $\begin{array}{c}\text { Frekuensi } \\
\text { meter } \\
(\mathbf{H z})\end{array}$ & $\begin{array}{c}\mid \text { Galat } \\
\mathbf{( \mathbf { H z } )}\end{array}$ & $\begin{array}{c}\text { Galat } \\
\text { Relatif } \\
(\%)\end{array}$ \\
\hline 1 & 1 & 50,03 & 50,04 & 0,01 & 0,02 \\
2 & 2 & 49,99 & 50 & 0,01 & 0,02 \\
3 & 3 & 49,98 & 50 & 0,02 & 0,04 \\
4 & 4 & 49,98 & 50 & 0,02 & 0,04 \\
5 & 5 & 49,98 & 50 & 0,02 & 0,04 \\
6 & 6 & 49,97 & 49,99 & 0,02 & 0,04 \\
7 & 7 & 49,97 & 49,98 & 0,01 & 0,02 \\
8 & 8 & 49,94 & 49,96 & 0,02 & 0,04 \\
9 & 9 & 49,94 & 49,96 & 0,02 & 0,04 \\
10 & 10 & 49,96 & 49,95 & 0,01 & 0,02 \\
& & Jumlah Galat & & 0,16 & 0,32 \\
\hline
\end{tabular}

Berdasarkan Tabel 1 dapat kita ketahui bahwa besar frekuensi listrik tidak stabil baik dari hasil pengukuran frekuensi meter maupun digital multimeter. Dari $10 \mathrm{kali}$ pengambilan data didapatkan jumlah galat sebesar $0,16 \mathrm{~Hz}$ dan jumlah galat relatif 0,32 . Dengan persamaan 4 maka didapatkan nilai galat relatif rata-rata.

$$
\text { Galat relatif rata }- \text { rata }=\frac{0,32}{10}=0,032 \%
$$

Nilai galat relatif rata-rata sebesar $0,032 \%$ ini menunjukkan bahwa alat ukur frekuensi meter telah bekerja dengan akurasi yang tinggi mendekati alat pembanding digital multimeter

\subsection{Pengujian Penampilan Data}

Pada pengujian ini, frekuensi meter akan mengirimkan data besar nilai frekuensi setiap 1 detik.. Pengambilan data dilakukan otomatis setelah memilih port komunikasi yang akan digunakan.

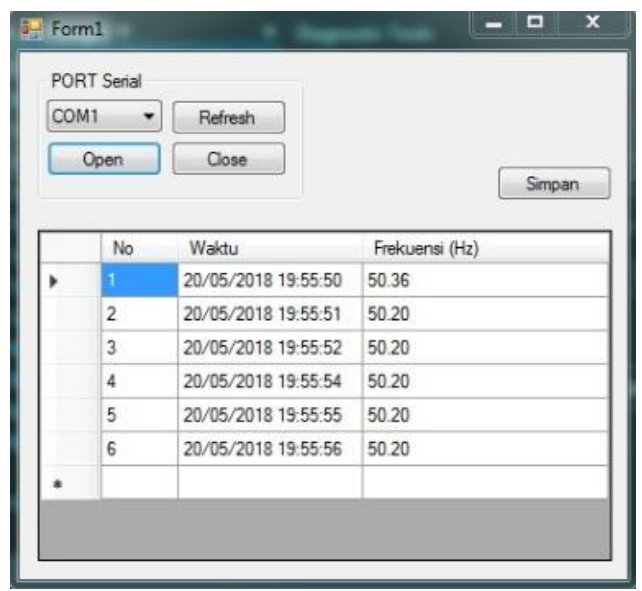

Gambar 9. Hasil Pengambilan data

Pada pengujian ini terlihat pada gambar 9 bahwa data yang ditampilkan telah benar dan juga menunjukkan posisi data yang sesuai dengan waktu diterimanya data.

\subsection{Pengujian Penyimpanan Data}

Pada pengujian ini dilakukan dengan interval pengambilan data 1 detik. Pengambilan data dilakukan secara otomatis setelah memilih port yang akan digunakan untuk komunikasi.

Pengambilan data dilakukan langsung setelah memilih port yang digunakan, hasil dari pengambilan data dapat dilihat tabel

Tabel 2. Hasil pengambilan data

\begin{tabular}{lc}
\hline Waktu & Frekuensi (Hz) \\
\hline 20/08/2018 12:04:52 & 50.04 \\
20/08/2018 12:04:53 & 50 \\
20/08/2018 12:04:54 & 50 \\
20/08/2018 12:04:55 & 50 \\
20/08/2018 12:04:56 & 50 \\
20/08/2018 12:04:57 & 49.99 \\
20/08/2018 12:04:58 & 49.98 \\
20/08/2018 12:04:59 & 49.96 \\
20/08/2018 12:05:00 & 49.96 \\
20/08/2018 12:05:01 & 49.95 \\
\hline
\end{tabular}

\subsection{Pengujian Pengukuran Frekuensi}

Pengujian ini dilakukan untuk mengetahui keakuratan alat. Pengujian dilakukan dengan membandingkan hasil pengukuran dengan bacaan pada Sanwa CD800a. Lokasi pengukuran dilakukan di Lab Elektronika Universitas 
Diponegoro. Pengujian ini dilakukan dengan mengambil data pada tanggal 20 Agustus 2018. Hasil pengukuran alat ukur dan alat pembanding dapat dilihat pada gambar 10 dan galat antara hasil pengukuran dengan pembanding dapat dilihat pada gambar 11 .
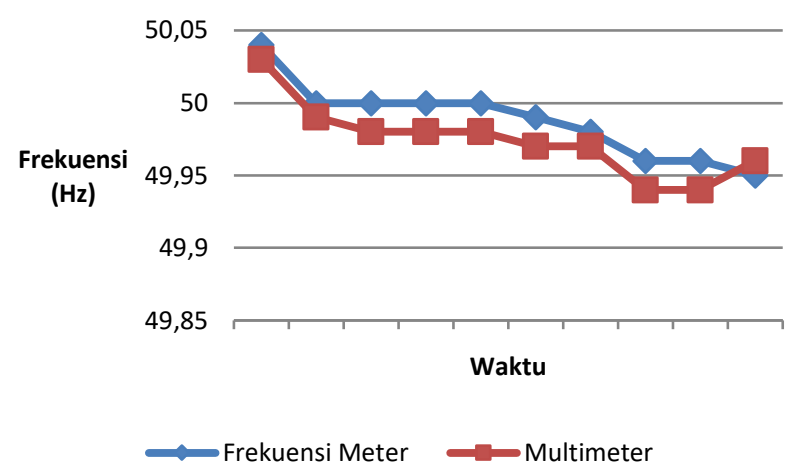

Gambar 10. Hasil Pengujian Pengukuran Frekuensi

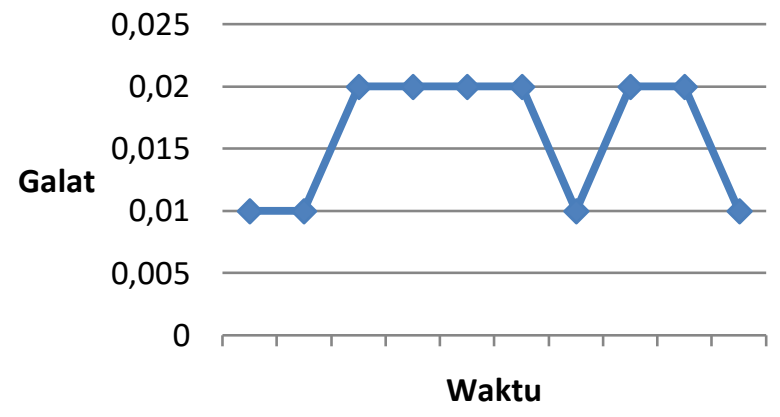

\section{Gambar 11. Galat Hasil Pengujian Pengukuran Frekuensi}

Pada Grafik 10 dan grafik galat 11 dapat dilihat bahwa akurasi dan ketelitian frekuensi meter listrik ini sudah cukup tinggi. Dimana dapat dilihat untuk galat hanya berada di kisaran 0,02 Hz. Hal tersebut menunjukkan bahwa alat yang di desain sudah berhasil.

\section{Kesimpulan}

Berdasarkan pengujian tiap perangkat yang dilakukan alat bisa berfungsi dan digunakan secara sempurna dan hasil pengukuran sudah sesuai dengan spesifikasi yang diinginkan dengan galat relatif rata-rata seluruh pengujian kurang dari $1 \%$. Berdasarkan hasil dari berbagai pengujian didapatkan besar frekuensi listrik yang terukur berada pada nilai 49,94-50,22 Hz. Berdasarkan hasil pengujian pengiriman data frekuensi penulis telah berhasil mengirimkan dan menampilkan data tersebut dalam bentuk tampilan pada komputer.

\section{Referensi}

[1]. F. Suryatmo, "Dasar-dasar teknik listrik," Rineka Cipta, Jakarta , 1996.

[2]. LIAO Yan,CHEN Li Xue,LAI Chun Hong, YE Ding Sheng, "The IP core design of frequency meter for equal precision based on FPGA" Application of Electronic Technique, South West Petroleum University, Chengdu China, 2007.

[3]. Loflin Lewis, "Zero-Crossing Detectors Circuits and Applications," Bristolwatch, 2016

[4]. S Svitlov, Ch Rothleitner, L J Wang, "Accuracy assessment of the two-sample zero-crossing detection in a sinusoidal signal", Metrologia, vol. 49, pp. 413, 2012.

[5]. Domenicantonio Grillo, Nicola Pasquino, Leopoldo Angrisani, Rosario Schiano Lo Moriello, "An efficient extension of the zero-crossing technique to measure frequency of noisy signals", Instrumentation and Measurement Technology Conference (I2MTC) 2012 IEEE International, pp. 2706-2709, 2012.

[6]. Atmel, "8bit AVR Microcontroller ATmega328-328P Datasheet," ATMega328.

[7]. Argent Data Systems, "Weather Sensor Assembly".

[8]. Datasheet PC817 Series. Sharp PC817XNNSZ0F .Tersedia : : http://www.sharpworld.com/products/device/lineup/data/pdf/datasheet/ pc817xnnsz_e.pdf 